\title{
What is More Effective in Student Representation: Information Field of Social Networks or Traditional Mass Media Communication?
}

\author{
Natalia S. Sakharova ${ }^{{ }^{*}}$ \\ (D) 0000-0002-1770-275x SC 57188834928
}

Tatjana V. Ezhova ${ }^{1}$

(D) 0000-0001-7985-3417 SC 55795473800 D AAB-7905-2020

Elena A. Ganaeva ${ }^{2}$

(iD) 0000-0002-9744-6134 SC 55801224700

Liubov G. Pak ${ }^{3}$

(iD) 0000-0001-7321-506X SC 57211777058 AAB-7972-2020

Ilgiz M. Sinagatullin 4

(iD) 0000-0003-1916-6724 SC 7801464600

Svetlana G. Kashina ${ }^{5}$

(iD) 0000-0003-2112-0637 SC 57073792400 I-5408-2018

Olga V. Popova ${ }^{6}$

(iD) 0000-0001-8142-0346 SC 56494433900 U-9759-2017

${ }^{1}$ Department of Foreign Languages, Orenburg State University, Orenburg, RUSSIA

2 Department of Education Management, Orenburg State University, Orenburg, RUSSIA

${ }^{3}$ Department of Pedagogics and Sociology, Orenburg State Pedagogical University, Orenburg, RUSSIA

${ }^{4}$ Department of Pedagogy and Methods of Pre-School and Primary Education, Birsk Branch of Bashkir State University, Birsk, RUSSIA

${ }^{5}$ Department of Construction Technology, Kazan State University of Architecture and Engineering, Kazan, RUSSIA

${ }^{6}$ Department of Legal Regulation of Economic Activity, Financial University under the Government of the Russian Federation, Moscow, RUSSIA

${ }^{*}$ Corresponding author: 8Helga-popova@yandex.ru

Citation: Sakharova, N. S., Ezhova, T. V., Ganaeva, E. A., Pak, L. G., Sinagatullin, I. M., Kashina, S. G., \& Popova, O. V. (2020). What is More Effective in Student Representation: Information Field of Social Networks or Traditional Mass Media Communication?. Online Journal of Communication and Media Technologies, 10(2), e202009. https://doi.org/10.29333/ojcmt/7930

ARTICLE INFO

Received: 25 Oct 2019

Accepted: 9 Mar 2020

\section{ABSTRACT}

The relevance of this article is to study a qualitatively new type of communication structures social networks in the Internet, as a special information channel, the important properties of which are: the speed of information flow, convergence, multimedia nature. All this requires special consideration of the formation of students' ideas about social reality in the new conditions. The purpose of the research is to analyze the information field of social networks in comparison with traditional mass media communication means in the student representation. Identification of specific features and patterns inherent in the Internet as a whole and social networks as its creation. Research methods: as a research method, we used the method of content analysis, which has sufficient diagnostic capabilities to study social networks on the Internet. Research results: the article considers the concepts of the information agenda and public arenas. Social networks as a means of mass communication are considered. The article analyzes the daily news formation in traditional mass communication media and in the social network. The features of the daily news formation in social networks through the eyes of

Copyright $\odot \mathbf{2 0 2 0}$ by authors; licensee OJCMT. This article is an open access article distributed under the terms and conditions of the Creative Commons Attribution License (http://creativecommons.org/licenses/by/4.0/). 
students are revealed. The novelty and originality of the study lies in the fact that the levels of mass media (traditional and new) are highlighted. It is shown that the mass communication media, in the view of students, use the achievements of industrial society and are characterized by limited time and space, low bandwidth, insufficient breadth of coverage, universality. Students highlight important properties of social networks: the speed of information flow, unlimited time and space, convergence, multimedia nature and personalization. First the factors affecting the features of the daily news' organization in social networks are identified: a larger number of news compared to the TV channel; the difference in the categories of news posted in social networks and on TV; differences in the content of the agenda of the communities themselves; discussion with users of the social networking news among the categories, which are less represented on $\mathrm{TV}$; the distribution in the network by ordinary users of only the most interesting news (viral reproduction). It is shown that under the guise of news on the studied television channel, the audience, in the view of students, receives outdated information while in social networks community members receive information at the speed of the events themselves. It was revealed that from the point of view of students, the number of news covering the events that took place on the eve of the event is approximately the same in the communities and on the TV channel. The phenomenon of citizen journalism in the representation of students is considered (social networks have a significant impact on the quality of journalism and its image in the eyes of Internet users). It is revealed that the interest of the student audience significantly differs in social networks from those topics of news that are shown on television. It is determined that from the point of view of students, the daily news in the social network communities contain significantly more negative news than on the TV channel, and less positive and neutral messages. It is shown that the daily news in social networks is formed spontaneously rather than purposefully installed. It is determined that the daily news in the networks more correspond to the needs of the student audience. Practical significance: marketers, image-makers, experts in the field of political technologies to verify the presence or absence of interest in a service or product, a public figure or a politician, can use the data obtained in this work. The findings can also be used in management psychology and social psychology.

Keywords: social networks, information agenda, news, Internet, student youth

\section{INTRODUCTION}

The relevance of the study is the growing popularity of social networks as a mass communication media in the student audience, their impact on the behavior of network participants. Traditional mass media (print media, television and radio) are losing revenue both from advertising, a large proportion of which goes to the Internet, and from falling circulation (Bayanova et al., 2019; Kargapoltseva et al., 2019). The network structure of social life is reflected not only in real, but also in virtual communities and leads to a decrease in the role of traditional mass media in society life. Statistics confirms this. The Internet has already surpassed the attendance of print media and radio. Russia lags behind Western countries in this respect, but this trend is also typical for Russian media. The Internet continues to grow its audience in contrast to Russian television. Considering social networks as a channel of mass communication, we note the exceptional impact of the information agenda on society (Alisov et al., 2018; Castels, 2000; Litvinov, 2012; McConnell \& Huba, 2008; Toffler, 2002).

The practice of media functioning shows that the information agenda in social networks is often different from the daily news in the classical mass media. Obviously, this is due to the technical gap between the channels themselves, because Newspapers and magazines are published with special frequency: once a day, week or month, news broadcastings on television and radio-once every half hour, hour or day, while the Internet in General, and social networks in particular, react immediately (Pushkarev et al., 2019). This is the first reason for the difference in agendas; the second is the specifics of such a communication channel as the Internet, which is unlimited in time and space, without owners and traditional clear management, allowing any user to generate information, providing the placement of multimedia content (Baibarin, Mashkin, \& Shelengovskiy, 2016). The third difference is the degree of knowledge of the news. Differences between news from the point of view of the student audience, lack of knowledge of such a communication channel as social networks, lead us to the problem of lack of knowledge about the mechanisms of the information agenda's formation in social networks. 


\section{LITERATURE REVIEW}

The study of mass communication as a social phenomenon began in the twenties of the twentieth century. It is considered that the German sociologist Max Weber, the founder of understanding sociology and the theory of social action, laid the beginning of mass communication research. He justified the need to study the press in a sociological aspect, described the method of analysis of the press, drawing attention to the orientation of the periodical press on various social structures and on the formation of personality, formulated social requirements for the journalist. Social relations form society as such, but the idea that the coexistence and interaction of people with each other can be represented in the form of a network has emerged relatively recently. Including up to the twentieth century, the structure of modern society is seriously different from the typical for the entire history of humanity, vertical social relations and its exact name is the network. In connection with the emergence of new media, the structure of social relations and the type of social relations are being reformed. The network-based social structure is highly dynamic and open to innovation without the risk of losing its balance. (Castells, 1999) Despite the fact that researchers have had a major impact on the study of social interactions, until the 50 s of the XX century, their interest was limited to the connections between individuals in small groups. The concept of social structure was not enough to represent the changing relationships in society as a whole. Currently, the study of social networks is an actively developing direction in many Sciences (Akhrenova, 2016; Baranov et al., 2019; Bloomer, 2001; Cherdymova et al., 2018a, 2018b; Dobrosklonskaya, 2013; Hilgartner, 2000; Putilina et al., 2019; Pokul, 2012; Zernetskaya, 2000). We have accumulated a rich mathematical apparatus that allows us to build complex models of social interactions, describing almost any social systems (Duzhnikova, 2012; Exler, 2006; Sazanov, 2010; Shapiro, 2000).

Social networks are, in our opinion, the largest mass communication media, and like any mass communication media, they have an agenda. In its most General form, communication is understood as an act of communication, a relationship between two or more individuals based on mutual understanding. As an information process, communication distinguishes between the sender (Communicator, message transmitter), the channel or means of transmitting information, the message itself, and the recipient of information, which further processes and interprets it (Delitsyn, 2010; Goroshko, 2009; Zavjalova et al., 2014). Maintaining and creating various social connections in the virtual space began with the birth of the Internet (e-mail, teleconferences, opportunities for interactive communication, and various chats). Initially, the task of all these communication tools was not so much communication, but rather the solution of business issues and work tasks. However, the social and entertainment function of the Internet quickly became one of the most important (Braslavets, 2009; Chugunov, 2000; Lavrenchuk, 2009; Sergeev, 2009). The social network provides many opportunities for self-presentation and the construction of a public image of the Self, with unlimited opportunities to control the impression produced. This creates a kind of competition for the number of friends, subscribers and attention among the participants of the networks.

\section{RESULTS AND DISCUSSION}

\section{The Tasks and Structure of the Study}

The General aggregate of the study is one hundred and twenty-five news reports of the TV channel program and eight thousand seven hundred and ninety-two news feeds of seven communities of the social network Vkontakte, as the most used by the student audience. The study took place over five days. Two hundred and seventy-seven news items remained on the social network after excluding full replays with copying to the same source, obscene messages and weather news. The TV channel included fifteen newscasts, with one hundred and twenty-five stories; after discarding the stories with full repeat and weather news, we received fifty-three news stories.

We analyzed two hundred and eighty news reports from eighty-two users and community organizers. Of the seven communities, five are news portals, and the news from there appear in community news feed, but two communities are supported by the interest of student users. In order to solve the tasks set by us to achieve the goal of the study, we have taken a number of actions: identified the main categories of news in the social network and on the TV channel; by analyzing the comments identified topics that cause increased 
interest among the audience of the social network; determined the nature of news in terms of their emotional color; studied the news in terms of the speed of their appearance in the agenda of the communities and the TV channel.

In addition, we solved the following problems identified in the study: we identified differences in terms of student youth between the daily news of communities; we compared the news of the TV channel and communities on such criteria as localization, the amount of advertising, news sources.

To achieve this goal, we set the following research tasks:

To identify the main categories of news.

To identify topics that are of high interest to the audience.

To determine the nature of the news.

To examine the news from the point of view of their appearance's source in the agenda.

We divided all reports into fourteen categories, presented in the following topics: business and economy; housing and utilities; road accidents; crime; emergencies; politics and management; culture, science and education; sports; construction; health; society; security; transport and roads; religion.

Having defined categories of news, we select the unit of analysis subject of the message. In this case, we consider each news report as a unit of account.

When conducting an analysis in a social network, you may encounter certain difficulties as a large amount of information (more than eight thousand messages and more than six thousand comments); frequent deletion of messages and comments by users themselves and community moderators; an abundance of links to third-party resources; multiple placement of the same news; copying, presence of a lot of obscene expressions that make it difficult to perceive; specific vocabulary (slang), grammatical errors; the presence of emoticons and other specific graphics inherent in Internet communication; leaving the discussion in a different direction; aggressiveness in discussions and disputes.

The main problem encountered in the application of content analysis is a lot of technical work.

\section{Research of Features of the Information Agenda in Social Networks as New Media}

At the first stage of the study, we paid attention to the revealed inconsistencies in the agendas of the social network and the TV channel:

only in $9 \%$ of news television raises the topic of transport and roads, while social networks raises it in a third of the studied messages;

the topic of religion does not interest the participants of social networks at all $-0 \%$, but the news with this topic is present on TV channel - 4\%;

Problems of housing and communal services, construction and security are given about the same attention in the social network (37\%) and on the TV channel (32\%). These are the only nearly identical topics.

After analyzing the fact of comments' presence or absence to the news in the social network according to the category of news, we can conclude that most of all participants are concerned about the situation with roads in the city. Students note that the timing of news, their number and scale of discussion depend on the size of the community, the number of participants. Since the news sample included the messages that appeared first in time in the predominant, because of the number of participants, communities, we analyzed more news. Students show that even in small groups there were unique news that caused a wide discussion. From this, we can conclude that the agenda of students who are members of several communities is wider than that of members of one community, and when these sources compete, the choice is often depends on the participant.

After consideration of news in both objects of study, from the point of view of localization, we discovered that the audience of a social network was not interested in the events of the province, and much less interested in regional events (13\%) than the events of the city (perhaps this is due to the fact that there is a very small percentage of residents of the regional districts in the community). In our view, this situation requires further consideration. In addition, the messages were divided into two groups: the first are informational, news-based, educational in nature, which is more valuable for reading, the second ones have 
an advertising component. On the studied TV channel, students noted $6 \%$ of news related to advertising events (film, dance show, ice show, etc.), the type of transport (regional air transport) and hidden propaganda of a political party. Students note that in communities, the number of such messages is twice as large, almost $11 \%$. In addition, students met with both hidden advertising (film, cartoon) and messages, organized by community organizers, which were announced as commercial messages. Comparing the time of news appearance and the time of the actual occurrence of events, students note that on the TV channel $15 \%$ of messages relate to events which took place a month ago, most news (67\%) mention the events of the previous week, $13 \%$ of news describe the events that occurred the day before, only $5 \%$ relate to the events of the current day. Social networks discussed the news of the previous month in $6 \%$ of messages, news of the week in $19 \%$ of messages, $20 \%$ of messages told us what happened the day before, and the rest (55\%) messages discussed the daily news. Students noted that the rate of news updates in the communities ranged from fifteen minutes to four hours. It is shown that the most large-scale is copying of someone else's information. Students note that the spread of information is on the principle of an avalanche process, rather exposed to copying interesting, dramatic information than ordinary. Copying acts as a viral editor, sifting out news that does not fall into the sphere of interests of users, and is one of the factors of the process originality of the agenda formation in social networks. It is interesting that in social networks all posted news fall into the field of view of users, any participant can post any news. Thus, the technical ability to host all news is a basic feature of social networks as a mass media, where the choice depends on the user, not external forces.

\section{CONCLUSION}

Studying social networks as a modern channel of mass communication, we see that they provide participants with much more opportunities than traditional social connections. Thanks to technological progress, networks give a different content to the concept of friends, they offer opportunities to manage the impression of themselves and open up prospects for professional, leisure and personal development, create new opportunities for communication.

The possibilities of social networks in the Internet, as media, are implemented in specific student practices of their use. They are based on the functions and goals of communication. The conditions for which are provided by online services tools of interaction, as well as supported by the structure of the social network as a communicative model that ensures the dissemination of information, the maintenance of group norms; effective use of existing contacts as a resource that makes up social capital.

Among the large number of characteristics of new media for students, the daily news is of particular interest. The information agenda is a spectrum of problems defined by mass communication media, presented to the audience in the form of a list of important topics, which forms the student audience's ideas about events in the world, or, in another way, constitutes a media reality. Social networks in the view of students in recent years have become the focus of public life on the Internet, transforming into a special information space, into the public arena. Networks provide such basic social functions as: communication of their members, exchange of opinions and information, formation of virtual interest groups, expert communities, business clubs, and are also used for the implementation of commercial and civil projects, exchange of multimedia content, news and other information. To this end, the developers have created an opportunity for student users to join so-called communities or interest groups. Students undoubtedly trust news, which is taken from the official websites of television companies, radio and Newspapers. This may be because before the Internet era, they were the legislators of the daily news. Despite the recorded increase in the influence of information on public life, on student youth, which is posted on social networks and blogs, they lose to news sites in terms of trust. In fact, this means that students read, discuss, share information in networks, but for its confirmation or denial use the sites of mass communication. It is obvious that most students to establish personal and business contacts use social networks; however, the technical principle of the network allows you to develop other areas of activity. The reality is that we actually use different facets of our live. Just before the time of social media, it was difficult to reflect the subtle minutiae of online identity. Just as in real life, boundaries are drawn between work and Hobbies, between family and friends, between adults and children, so are boundaries drawn in online social networks. The continuous, informal and mediated communication of students that occurs on social networks allows their participants to inform their 
friends about new opportunities in a passive mode by publishing information in their profiles or statuses. From the point of view of students, in the absence of online social networks, there would probably be no way to learn about the available opportunities, since they are outside the everyday circle of communication. In reality, understanding the mechanisms of folding the daily news in the networks will open the horizons of society's transformation, open the prospects of changing public interests, reveal the degree of commonality or break with traditional types of social structure.

In social terms, the question of students' perceptions of the daily news is obviously related to the formation of an active civil society, socially active groups, and the emergence of political and social movements. The news of the day reflects specific features of social life, bears the imprint of social problems of the local population, and is important both at the regional and Federal levels. The daily news and its circumstances allow us to see in a new way the problems of civil society, which include the key human rights to free access to information, to freedom of speech, to the completeness and objectivity of information.

\section{REFERENCES}

Akhrenova, N. A. (2016). Internet linguistics: a new paradigm for describing the language of the Internet. In: Bulletin of the Moscow state regional University, 3, 8-14. https://doi.org/10.18384/2310-712X-2016-3-8-14

Alisov, E. A., Cherdymova, E. I., Trubina, G. F., Yakushev, A. N., Zhdanov, S. P., Popova, O. V., \& Kobzar-Frolova, M. N. (2018). Study of Dominant Type of Student Ecological Focus. Ekoloji, 27(106), 357-362.

Baibarin, A. A., Mashkin, N. A., \& Shelengovskiy, P. G. (2016). The Northwest Caucasus from Ancient Times to the 19th Century: A Historiographical Review of the Recent Publications in the Periodicals. Rusin, 46(4), 119-140. https://doi.org/10.17223/18572685/46/8

Baranov, V. V., Cherdymova, E. I., Novikov, S. B., Lukina, E. V., Kazurov, O. A., Korzhanova, A. A., \& Gurbanov, R. A. (2019). Student attitude to ethical consumption as new ecological practice. In: Humanities \& Social Sciences Reviews, 7(4), 1173-1179. https://doi.org/10.18510/hssr.2019.74160

Bayanova A. R., Vodenko K. V., Sizova Zh. M., Chistyakov A. A., Prokopiev A. I., \& Vasbieva D. G. (2019). A Philosophical view of organizational culture policy in contemporary universities. In: European Journal of Science and Theology, 15(3), 121-131.

Braslavets, L. A. (2009). Social networks as a mass media: to the problem statement. In: Bulletin of VSU. Series: Philology and journalism, 1, 11-13.

Cherdymova, E. I., Afanasjeva, S. A, Parkhomenko, A. G., Ponyavina, M. B., Yulova, E. S., Nesmeianova, I. A., \& Skutelnik, O. A. (2018a). Student ecological consciousness as determining component of ecologicaloriented activity. EurAsian Journal of BioSciences Eurasia J Biosci, 12, 167-174.

Cherdymova, E. I., Vorobyeva, K. I., Romashkova, O. V., Mashkin, N. A., Grigoriev, S. M., Romanchenko, L. N., Karpenko, M. A., \& Bayanova, A. R. (2018b). Photo Exhibition Influence on Student Environmental Consciousness Formation. Ekoloji, 27(106), 1271-1278.

Chugunov, A. V. (2000). Politics and the Internet: political communication in the conditions of development of modern information technologies: abstract of PhD Thesis in polit. sciences. St.Petersburg, 24 p.

Delitsyn, L. L. (2010). Will the Internet user soon become like the average Russian. Online research in Russia 2.0. Moscow: Publishing house RIC “North-East”, pp. 31-42.

Dobrosklonskaya, T. G. (2013). Methodology for the analysis of media texts in terms of converged media. Development of the Russian-language media space: communication and ethical problems: materials of the scientific and practical conference (May 26-27, 2013). Moscow: Publishing house of Academy of advanced training and professional retraining of education workers, pp. 18-27.

Duzhnikova, A. S. (2012). Social networks: modern trends and types of use. In: Public opinion monitoring: economic and social changes, 5, 238-251.

Exler, A. (2006). Communication on the Internet. Moscow: publishing house NT Press. 370 p.

Goroshko, E. I. (2009). Information and communication society in the gender dimension. Kharkov: FLP publishing house. $816 \mathrm{p}$.

Kargapoltseva, N. A., Rakhimova, O. N., Shabalina, L. G., Guryanova, T. Y., Mashkin, N. A., Mirzalimov, R. M., \& Popova, N. F. (2019). Student Identity and Various Procedures of its Development. International Journal of Applied Exercise Physiology, 2(1), 519-526. 
Lavrenchuk, E. A. (2009). Autopoiesis of social networks of Internet communications. Bulletin of Russian state University for the Humanities, 12, 48-56.

McConnell, B., \& Huba, D. (2008). Content Epidemic. Marketing in social networks and the blogosphere. Moscow: Vershina publishing house.192 p.

Pokul, V. (2012). Motivational activity of the individual in social media and management of marketing communications. Materials of the III all-Russian scientific and practical conference "Actual problems of personnel management and organizational psychology". Krasnodar, pp. 83-86.

Pushkarev V. V., Cherdymova E. I., Prokopyev A. I., Kochurov M. G., Shamanin N. V., Ezhov S. G., Kamenskaya S. V., \& Kargina N. V. (2019). Requirements for Green Restoration and Renovation of Existing Buildings. Dilemas contemporáneos: Educación, Política y Valores, VI, Special Edition, p. 41.

Putilina, E. S., Cherdymova, E. I., Kurbanov, R. A., Belyalova, A. M., Shatskaya, I. I., Kobzeva, E. I., Zhuravleva, M. V., \& Meleshko, G. S. (2019). Ecological relationships in real and virtual environments: contact points. EurAsian Journal of BioSciences Eurasia J Biosci, 13, 1475-1480.

Sergeev, E. Yu. (2009). Mass communication media in the conditions of globalization. Society. Environment. Development, 1, 117-126.

Shapiro, D. I. (2000). Man and the virtual world. Cognitive, creative, and applied problems. Moscow: AST. 200 p.

Toffler, E. (2002). Shock of the future. Moscow: publishing house "AST publishing house". 557 p.

Zavjalova, Z. S., Kondratieva, I. V., Giniyatova, E. V., \& Dikin, E. (2014). Communicative transformations of social media. News of Tomsk Polytechnic University. Social and humanitarian technologies, 325(6), 87-93.

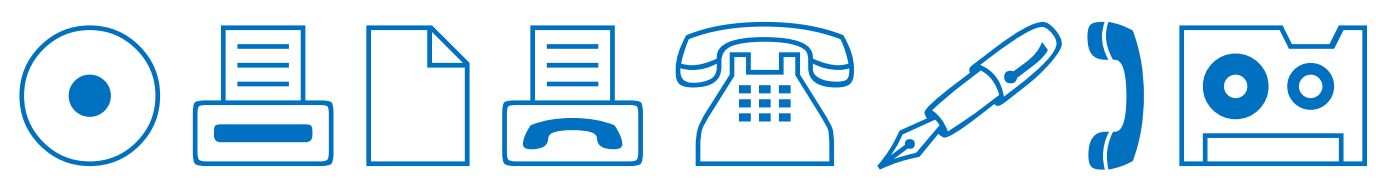

